\title{
TEORIA I METODOLOGIA ARCHEOLOGII NA UNIWERSYTECIE W POZNANIU
}

\section{THEORY AND METHODOLOGY OF ARCHAEOLOGY AT THE UNIVERSITY IN POZNAŃ}

\author{
Danuta Minta-Tworzowska \\ Instytut Prahistorii, Uniwersytet im. Adama Mickiewicza \\ ul. Św. Marcin 78, 61-809 Poznań, Poland \\ Michat Pawleta \\ Instytut Prahistorii, Uniwersytet im. Adama Mickiewicza \\ ul. Św. Marcin 78, 61-809 Poznań, Poland
}

\begin{abstract}
The article attempts to present and evaluate the role and achievements of the Department of History and Methodology of Prehistory at the Institute of Prehistory at Adam Mickiewicz University, in terms of a reflection on theory and methodology of archaeology, developed in the framework of the Department, and pioneered by Professor Jan Żak. The first part presents an overview of the theoretical reflection and the range of issues undertaken by Professor Żak, while the second, by the employees of the Department of History and Methodology of Prehistory after Professor's death. What all of these share is an attempt to find answers to questions about what is a "theory" in archaeology, what is its relationship with the practice of the discipline, the humanities and the intellectual world in general, as well as the role it played in the development of Polish archaeology in the past few decades.
\end{abstract}

Rzeczywista historia jest dramatem, który na użytek maluczkich wciąz przerabia się na czytankę z prostym moratem.

(Szacki 2001, s. 56)

\section{WPROWADZENIE}

Rzeczą niezmiernie trudną jest próba podjęcia w miarę obiektywnego przedstawienia oraz oceny roli i dorobku Zakładu Historii i Metodologii Prahistorii Instytutu Prahistorii UAM - w zakresie rozwijanej w jego ramach refleksji nad teorią i metodologią archeologii, zapoczątkowanej kilka dekad temu przez Profesora Jana Żaka. 
Nie można w tym przypadku doszukiwać się ewolucyjnego bądź linearnego rozwoju poglądów oraz refleksji i konsekwentnie antycypować obrazu pewnej zunifikowanej i w miarę jednorodnej szkoły myślowej: przyjmuje ona raczej postać deleuzjańskiego kłącza, odchodzących od siebie oraz pączkujących części. W tym konkretnym przypadku nie tylko teoria, lecz także praktyka dowodzą niezwykłej złożoności zagadnień teoretycznych $\mathrm{w}$ archeologii, a poszczególne ścieżki intelektualne pracowników Zakładu stanowią wyraz własnych prób poszukiwania paradygmatów i własnej refleksji nad rolą teorii $w$ archeologii. Jedną, wspólną dla wszystkich płaszczyzną jest niesłabnące przekonanie o ważności teorii $\mathrm{w}$ archeologii i praktyce archeologicznej na każdym etapie jej badań oraz konieczność hołdowania rygoryzmowi metodologicznemu.

Wydzielić można kilka głównych płaszczyzn, charakteryzujących główne pola zainteresowań i rozwijanej refleksji, których spoiwem są niezmiennie teoria i metodologia archeologii, wykraczające jednakże poza wąski horyzont archeologii. Wiele pytań, które się pojawiają, dotyczą tego, czym jest „teoria”, jaki jest jej związek z praktyką archeologiczną, naukami humanistycznymi i światem intelektualnym w ogóle, a także: jaką rolę odegrała ona w rozwoju archeologii w ciągu kilku ostatnich dziesięcioleci. W niniejszym artykule podjęta zostanie próba częściowej odpowiedzi na powyższe pytania poprzez ogólny zarys refleksji teoretycznej i analizowanych zagadnień przez Jana Żaka oraz po Jego śmierci: w ramach Zakładu Historii i Metodologii Prahistorii.

\section{REFLEKSJA TEORETYCZNA PROFESORA JANA ŻAKA}

W powojennej archeologii poszukiwano nowych rozwiązań teoretycznych i metodologicznych. Szeroko dyskutowano problemy prehistorii - prahistorii - archeologii; starano się wówczas zacierać granice między prahistorią a historią. W tej dyskusji dużą rolę w latach 60. odegrali Witold Hensel, uczeń Józefa Kostrzewskiego, związany z Poznaniem (w latach 1951-1956 kierował Katedrą Archeologii Polski i Powszechnej), oraz Jan Żak. Obaj formowali nowe spojrzenie na podstawowe problemy tej dyscypliny, tak jak były one rozumiane w latach 60., 70. i 80. ubiegłego stulecia.

Termin archeologia. Kwestią podstawową dla dyscypliny zajmującej się dawną historią był sam termin, a więc: archeologia. Problem relacji archeologia a prahistoria był bardzo ważny zarówno dla W. Hensla, jak i dla J. Żaka, a także dla wielu archeologów w tamtym czasie, podejmujących próbę odpowiedzi na pytanie o zakres i specyfikę archeologii. J. Żak już w artykule z 1966 r. zatytułowanym „Historia pierwotna i jej współczesne metody" przeprowadził gruntowną refleksję nad nauką zajmującą się dziejami „,społeczeństw pierwotnych”. Rozważył on odpowiedniość terminów prehistoria (przed-historia), prahistoria (dawna historia), archeologia 
dla nauki zajmującej się pradziejami ${ }^{1}$. Kolejne terminy to archeologia pierwotna (pradziejowa) i historia pierwotna oraz antropologia kulturowa ${ }^{2}$. Profesor Jan Żak za najbardziej odpowiedni - pod kątem wymogów ówczesnej nauki i swoich oczekiwań - przyjął wówczas termin historia pierwotna, jako jedna z dyscyplin historycznych w szeregu: historia pierwotna, starożytna, nowożytna, współczesna. Archeologię (pierwotną) uznał Profesor za podstawową (ramową) naukę i zarazem metodę historii pierwotnej - zajmującą się badaniem działalności ludzkiej, wytworów, myśli i dążeń jednostki oraz społeczeństwa o tyle, o ile działalność ta pozostawiła konkretne ślady głównie w postaci materialnych pozostałości ${ }^{3}$. J. Żak stał konsekwentnie na stanowisku, że archeologia to nauka historyczna ${ }^{4}$. W późniejszych publikacjach zmodyfikował swoje poglądy i opowiedział się w duchu poglądów W. Hensla, wyrażonych w pracy Archeologia i prahistoria ${ }^{5}$. To jednak W. Hensel we wspomnianej pracy zaproponował i narzucił pojmowanie relacji tych dziedzin w Polsce. Obaj badacze uznali więc prahistorię za naukę samodzielną, syntetyzującą pradzieje, odpowiednik historii dla czasów przedpiśmiennych; natomiast archeologię pradziejową uznali za dyscyplinę samodzielną, podstawową dla prahistorii, a ,pomocniczą" dla różnych działów historii. Zarówno W. Hensel, jak i J. Żak w praktyce stosowali terminy prahistoria i archeologia, przyjmując, że w odniesieniu do pradziejów ziem polskich ich zakresy są prawie zbliżone. O silnym wpływie tych poglądów świadczy choćby nazwa poznańskiego Instytutu, mianowicie: Instytut Prahistorii, choć dyskusje te już dawno przebrzmiały.

Poszukiwanie teorii. Kolejny obszar refleksji J. Żaka to poszukiwanie teorii. W latach 60. uległ on ówczesnemu wyobrażeniu, a zarazem złudzeniu, iż zmiana teorii naukowych (paradygmatów) dokonuje się „rewolucyjnie”, co nawiązywało bezpośrednio do postrzegania rozwoju nauki jako zmiany paradygmatów, dokonującej się w sposób rewolucyjny, opisanej w pracy Thomasa Kuhna Struktura rewolucji naukowych ${ }^{6}$. Istotny był tu wpływ idei T. Kuhna - że tworzenie wiedzy jest ukierunkowane i nie może wychodzić z niczego, jak to postrzegano wcześniej, ponieważ wymaga teorii, punktu widzenia, który pozwoli oddzielić to, co istotne, od tego, co nieistotne. Ponadto pozwoli również wskazać tereny badań, które przyniosą najwięcej korzyści - które stały się inspiracją i znalazły odbicie w sposobie myślenia prezentowanym w pracach Jana Żaka. Najlepszym tego dowodem jest Jego krytyka pozytywistycznej archeologii jako przedteoretycznej z obecnym $\mathrm{w}$ niej indukcjonizmem i naturalizmem, a zwrot ku marksizmowi i strukturalizmowi jako teorii społecznej, dzięki której archeologia będzie mogła dokonać przełomu metodologiczne-

\footnotetext{
${ }^{1}$ Żak 1966, 67, 68.

${ }^{2}$ Żak 1966, 69-71.

${ }^{3}$ Żak 1966, 74, 75.

${ }^{4}$ Żak 1968.

${ }^{5}$ Żak 1971.

${ }^{6}$ Kuhn 1968.
} 
go. Dążeniem Jana Żaka było więc przekształcenie archeologii w naukę z trwałą, wyjaśniającą pradzieje, teorią.

Podejście teoretyczne w nauce. Profesor Jan Żak opowiedział się za podejściem teoretycznym w nauce, kształtowanym przez metodologiczną szkołę poznańską z Jerzym Kmitą i Leszkiem Nowakiem na czele. Przedstawicielem tej szkoły na gruncie historii był natomiast Jerzy Topolski. Jan Żak uczestniczył w opracowywaniu syntez dziejów Polski pod redakcją Jerzego Topolskiego - i wówczas stało się widoczne to, jak trudno archeologii nawiązać kontakt z formą dyskursu historycznego. Jednak wtedy wydawało się, że szkoła ta będzie podstawą przebudowy teoretycznej, również w archeologii, oraz że dostarczy w tym zakresie podstaw metodologicznych. Profesor Żak opowiedział się właśnie za tym nurtem w najbardziej wyraźny sposób w latach 80 . Konsekwencją tego były Jego zainteresowania problematyką społeczną, a osłabienie zainteresowania problematyką kulturową. Profesor starał się przedstawiać $\mathrm{w}$ modelowy sposób przemiany i procesy zachodzące $\mathrm{w}$ pradziejach i we wczesnym średniowieczu, z zastosowaniem zasady sprzeczności w odniesieniu do podstawowych czynników gospodarczych. Dostrzegał nowe prądy i tendencje intelektualne, powstające zarówno na gruncie historii, jak i nauk kulturoznawczych, a także w filozofii nauki. To stworzyło dlań płaszczyznę odcinania się od ograniczeń narzucanych przez własną dyscyplinę naukową, jaką była archeologia. Można dyskutować i polemizować, czy nawiązanie do marksizmu było tą właściwą płaszczyzną ,modernizowania” archeologii, jednak poszukiwał on nowej teorii czy pewnych inspiracji, które pozwoliłyby archeologii stać się nauką nowoczesną.

Jan Żak ${ }^{7}$ wyraźnie natomiast polemizował $\mathrm{z}$ drugim nurtem: $\mathrm{z}$ teorią ewolucji biokulturowej Janusza Piontka ${ }^{8}$; dostrzegał jednak pozytywy adaptacji tej teorii w archeologii. Uważał bowiem, że powstawanie różnych ujęć teoretycznych tej samej problematyki jest źródłem postępu naukowego. Dziś można na to zagadnienie spojrzeć jeszcze z innej perspektywy. W archeologii istnieje wiele dróg, teorii, które są jedną z możliwych dróg uprawiania nauki, trudno zatem spodziewać się ,rewolucji naukowej" w archeologii.

Dążeniem J. Żaka było poszukiwanie teorii, która pozwoliłaby na wyjście archeologii z szeroko rozumianego pozytywizmu. We wszystkich pracach dostrzec można Jego wiarę $\mathrm{w}$ istnienie $\mathrm{i}$ formułowanie jasnych podstaw teoretycznych i metodologicznych. Jest to szczególnie wyraźne w studiach nad osadnictwem. Na temat osadnictwa wypowiedział się on w dwóch artykułach: „O studiach osadniczych” oraz "Uwagi metodologiczne nad problemem osadnictwa" ", a także angażował się w polskie tłumaczenie pracy Herberta Jankuhna ${ }^{11}$ o osadnictwie. Studia osadnicze

\footnotetext{
${ }^{7}$ Żak 1988.

${ }^{8}$ Piontek 1988.

${ }^{9}$ Żak 1977.

${ }^{10}$ Żak 1985a.

${ }^{11}$ Jankuhn 1983.
} 
były wyznacznikiem Jego czasów. W ujęciu osadnictwa J. Żak odchodzi od powszechnego wówczas determinizmu geograficznego. Uważa, iż osadnictwo stanowi egzemplifikację relacji społeczeństwa do jego naturalnego środowiska przestrzennego; to człowiek, dysponujący określoną gospodarką, determinuje osadnictwo i je modyfikuje, tym samym zmienia środowisko.

Kontynuacja osadnictwa na ziemiach polskich. Ważnym problemem teoretycznym, metodologicznym i praktycznym była kwestia kontynuacji osadnictwa na obecnych ziemiach polskich w V/VI w. n.e. Jan Żak podjął próbę przeformułowania pozytywistycznego problemu ,ciągłości/nieciągłości” osadniczej, rozumianego w kategoriach ciągłości występowania zabytków w nieprzerwanej sekwencji warstw kulturowych na danym obszarze. Profesor wprowadził jego teoretyczne rozumienie jako zróżnicowanego czasoprzestrzennie i funkcjonalnie procesu przemian, ujmując go jako kwestię kontynuacji bądź dyskontynuacji bytu społecznego i kulturowego ${ }^{12}$. Wskazał na najistotniejszą kwestię na tym poziomie rozważań, a mianowicie: przyjęcie krótkiej bądź długiej chronologii. To ona, Jego zdaniem, decyduje o przyjęciu istnienia hiatusu bądź jego braku. Ważnym obszarem aplikacyjnym dla tego problemu był schyłek starożytności i wczesnego średniowiecza na ziemiach polskich. Dotyczyło to zwłaszcza problemu etnogenezy Słowian. Z tego zakresu powstała znakomita i erudycyjna praca Stowianie i Germanie w prahistorii polskiej i niemiec$k i e j^{13}$, uwzględniająca osiągnięcia językoznawstwa, historii i archeologii. J. Żak dostrzegał wyraźnie nieefektywność badań nad etnogenezą w następujących cechach tych badań: w pozytywistycznym modelu nauki; w korelacji kultur archeologicznych ze wspólnotą językową ( $\mathrm{z}$ etnosem); w podjęciu rekonstrukcji etnokultury; w doborze źródeł (fetyszyzacji źródeł archeologicznych), z jednoczesnym pomijaniem źródeł językoznawczych ${ }^{14}$. Zagadnienie to $\mathrm{w}$ aspekcie hiatusu podjął następnie Stanisław Tabaczyński ${ }^{15}$, ponownie Jan Żak ${ }^{16}$, nieco później zaś Anna Pałubicka wraz ze Stanisławem Tabaczyńskim ${ }^{17}$. W duchu prawie postmodernistycznym, wyprzedzając swój czas, J. Żak podszedł do zagadnienia refleksji prahistorycznej. Zajmował się refleksją człowieka pradziejowego i nowożytnego na temat własnej przeszłości $^{18}$. Dostrzegał zasadnicze różnice w myśleniu i ujmowaniu świata przez ludzi pradziejowych i nowożytnych, ukazując, w jaki sposób sprzeczności wewnętrzne prowadzą do zmian. Świadomość ujmował jako odbicie warunków życia ludzi oraz jako regulator tegoż życia. Tak więc świadomość w Jego ujęciu to wiedza, magia, religia i ideologia rodowo-plemienna. Profesor zbudował model dotyczący refleksji

\footnotetext{
${ }^{12}$ Żak 1980, 1985b.

${ }^{13}$ Żak 1974.

${ }^{14}$ Żak 1974, 149.

${ }^{15}$ Tabaczyński 1985.

${ }^{16}$ Żak 1985b.

${ }^{17}$ Pałubicka, Tabaczyński 1986.

${ }^{18}$ Żak 1975.
} 
człowieka, jednak zrealizował część tego zamysłu; stworzył model świadomości społeczeństw paleolitycznych strefy śródziemnomorskiej, określając go jako naiwno-naturalistyczny ${ }^{19}$.

Przegląd problematyki teoretyczno-metodologicznej wskazuje na szeroki wachlarz podejmowanych przez J. Żaka zagadnień, pytań badawczych, które były istotne w ówczesnej archeologii. Profesor rozważał tradycyjne pytania, ale odchodził od ich tradycyjnego rozwiązania, co nie spotkało się z powszechnym zrozumieniem. W pewnym zakresie wyprzedził on swoją epokę. Jego myśli i inspiracje były rozwijane, poszerzane czy zmieniane $\mathrm{w}$ ciągu ostatnich 20 lat $\mathrm{w}$ pracach archeologów poznańskich, warszawskich i innych.

\section{REFLEKSJA ROZWIJANA W ZAKŁADZIE HISTORII I METODOLOGII PRAHISTORII}

Zakres problematyki podejmowanej w ramach Zakładu Historii i Metodologii Prahistorii jeszcze za życia, lecz głównie po śmierci Jana Żaka, jest zbyt obszerny, by mógł być przedmiotem systematycznego ujęcia; można jednak wydzielić w niej pewne wiodące pola badawcze. Pomimo charakteryzującej je różnorodności, uzyskują one jedność na płaszczyźnie teoretycznej i powinny być ujmowane jako przejaw rozwijanej refleksji nad rolą teorii i metodologii w archeologii. Istotnym programem badawczym, zapoczątkowanym przez Profesora J. Żaka i kontynuowanym do dnia dzisiejszego, stanowią szeroko zakrojone studia nad podstawami metodologiczno-teoretycznymi archeologii, którą Instytut Prahistorii UAM w Poznaniu, jako jeden z niewielu ośrodków archeologicznych w Polsce, od wielu lat w konsekwentny sposób realizuje. Istotny, a tym samym określający również charakter Zakładu oraz podejmowanych $w$ jego ramach zagadnień i rozwijanej refleksji, wydaje się postulat interdyscyplinarności badañ ${ }^{20}$, pozostający nie tylko w warstwie deklaratywnej, lecz realizowany na płaszczyźnie praktycznej, m.in. poprzez odnoszenie się do metodologii nauk humanistycznych, filozofii nauki, metodologii historii, zagadnień z antropologii kulturowej, zbliżenie się do nauk ścisłych (procedury badawcze, baza empiryczna) czy zabieranie aktywnego głosu w dyskusjach toczonych na polu współczesnej humanistyki. Ma ona na celu konceptualizację badań i praktyki archeologicznej w XXI w. Wśród płaszczyzn badawczych wyróżnić można kilka wiodących, które chcielibyśmy przedstawić.

Koncepcje źródła $w$ archeologii. Jedną z podstawowych płaszczyzn zainteresowań jest konceptualizacja i krytyczna refleksja nad koncepcją źródła w archeologii oraz funkcji, jaką spełnia ono $w$ jej procesach poznawczych ${ }^{21}$. Z perspektywy ar-

\footnotetext{
${ }^{19}$ Żak 1974/1975.

${ }^{20}$ Zob. Minta-Tworzowska 2006a.

${ }^{21}$ Minta-Tworzowska 1998, 2000c, 2012.
} 
cheologii to niezwykle istotne zagadnienie, ponieważ kultura materialna stanowi rdzeń badań archeologicznych - i na jej podstawie wysuwane są, oczywiście sterowane przyjmowaną opcją badawczą czy teorią, wnioski oraz interpretacje dotyczące pradziejów. W ramach refleksji nad źródłem archeologicznym zajmowano się również procesami źródłotwórczymi, a także rozwijano metodykę podejścia do badań i analizy źródeł faunistycznych, oraz procesami tafonomicznymi ${ }^{22}$. W tym nurcie mieści się również szeroka i krytyczna refleksja na temat zdjęć lotniczych jako istotnego źródła danych o obiektach archeologicznych i roli tej kategorii źródeł w praktyce archeologicznej ${ }^{23}$.

Klasyfikacja i typologia $w$ archeologii. Rozważania nad klasyfikacją wynikły z zainteresowań procedurą badawczą archeologii i najpełniej zaprezentowane zostały w pracy Danuty Minty-Tworzowskiej z 1994 r.: Klasyfikacja jako sposób wyrażania wyników badan, hipotez i teorii archeologicznych. Klasyfikacja powinna być rozumiana jako swoista oś archeologii, wokół której starano się zbudować metodologię, wyrażającą ideę nowoczesnej archeologii, odwołującej się do kategorii kultury, działań ludzkich czy określonych konstrukcji teoretycznych ${ }^{24}$. Zagadnienie klasyfikacji w archeologii nie ma charakteru neutralnego, ale jest ono wieloaspektowe. Wraz ze zmianą kierunków konceptualizacji w archeologii, np. archeologia kulturowo-historyczna, podejście procesualne, francuska szkoła logicystyczna, strukturalizm czy archeologia kontekstualna, zmienia się także obraz klasyfikacji w archeologii, co nie pozostawało bez wpływu na sposoby definiowania pojęć, formułowania hipotez $\mathrm{i}$ teorii $\mathrm{w}$ archeologii oraz sposoby wyrażania i prezentowania wyników badań.

Teoria i metodologia $w$ archeologii. Ściśle powiązana z zagadnieniami źródła archeologicznego oraz klasyfikacji i typologii jest refleksja nad procedurami badawczymi archeologii. W jej ramach zarysowuje się szeroki nurt refleksji, który można odnieść do kilku zagadnień omówionych poniżej.

Krytyka archeologii pozytywistycznej (kulturowo-historycznej), wyrażająca się w odrzuceniu serwowanego przez nią modelu badań pradziejów (m.in. indukcjonizmu, naturalizmu, obiektywizmu, ewolucjonizmu, dyfuzjonizmu, pojmowanego jako rozprzestrzenianie się wytworów i idei bez współdziałania czynnika ludzkiego itd.). Odrzucenie tychże założeń nie prowadziło do poznawczej aporii, a wprost przeciwnie - wiązało się z poszukiwaniem „lepszej” teorii i modelu badań pradziejów ${ }^{25}$. W tym nurcie poszukiwań umieścić można zdecydowany głos w kwestii, czy archeolog rekonstruuje czy konstruuje wizerunki przeszłości, z wyraźnym opowiedzeniem się za opcją konstruktywistyczną, w myśl której przeszłość jest każdorazo-

${ }^{22}$ Marciniak 1996, 2005; zob. niżej.

${ }^{23}$ Rączkowski 2002; zob. niżej.

${ }^{24}$ Zob. też Minta-Tworzowska 1998b.

${ }^{25}$ Zob. Minta-Tworzowska 1987; Marciniak, Rączkowski 1991; Marciniak 1996, 2006b; Minta-Tworzowska, Rączkowski 1996, 2007, 2009/2011, 2012a. 
wo konstruowana przez badającego ${ }^{26}$, a także opisanie strategii narratywizacji w archeologii ${ }^{27}$. Wyraźny w tych rozważaniach jest aspekt źródła archeologicznego, z odrzuceniem wszak naiwnej wiary, że w źródłach tych zawarta jest prawda o przeszłości, że ich kumulatywny przyrost pozwala na pełniejsze i obiektywne wyjaśnianie przeszłości, czy wreszcie, że praktyka archeologiczna dotyczy odkrywania prawdy o przeszłości ukrytej w źródłach. Ważnym elementem krytyki była też wpisująca się w nurt antypozytywistyczny refleksja, że kultura archeologiczna nie stanowi bytu w sensie ontologicznym, a więc realnie istniejącego, lecz jest jedynie narzędziem porządkującym materię archeologiczną na użytek archeologów. Wreszcie, istotne jest również zdecydowane stanowisko w kwestii etniczności - ze wskazaniem, iż nie można nadawać wyróżnianym na takiej zasadzie bytom, czyli „kulturom archeologicznym”, statusu jednostek etnicznych, ponieważ kultura archeologiczna nie jest tożsama z grupą etniczną ${ }^{28}$.

Poszukiwania paradygmatu w mnogości teorii. Krytyka archeologii kulturowo-historycznej doprowadziła nie tylko do odrzucenia jej podstawowych tez i założeń, lecz także skłaniała ku dalszym poszukiwaniom, których motywem przewodnim było przeświadczenie o kluczowej roli, jaką odgrywa teoria w procedurach archeologicznych. Teoria może być rozumiana jako pewien spójny system praw nauki, zintegrowany według pewnej jednolitej zasady wyjaśniania. Pełni ona funkcje eksplanacyjne i musi spełniać warunki poprawności logicznej, przy czym istotna jest jej empiryczna sprawdzalność. Krytyka archeologii pozytywistycznej i przejście na etap teoretyczny doprowadziły do nieuniknionego flirtu $\mathrm{z}$ elementami teorii marksistowskiej, a także $\mathrm{z}$ archeologią procesualną, strukturalistyczną, i następnie $\mathrm{z}$ archeologiami postprocesualnymi/interpretatywnymi ${ }^{29}$. Niemniej towarzyszyło im przekonanie, iż w archeologii nie da się utrzymać tezy o niewspółmierności następujących po sobie teorii, która to miałaby polegać na braku logicznych związków następujących po sobie paradygmatów, a że raczej mamy do czynienia ze zjawiskiem wchłaniania dotychczasowej teorii przez nową teorię i lepszym tłumaczeniem przez nią rzeczywistości społecznej ${ }^{30}$. W takim ujęciu stanowisko to bliskie jest myśli neopragmatycznej, zakładającej, iż w archeologii użyteczna jest taka teoria, która najpełniej i w sposób najbardziej spójny interpretuje fragment przeszłej rzeczywistości.

Zainteresowania pracowników Zakładu można lokować ogólnie w kilku nurtach teoretycznych: (1) archeologii procesualnej, ze świadomością jej ograniczeń, np. determinizmu ekologicznego i geograficznego, imputacji założeń współczesnego racjonalizmu itd.; (2) archeologii procesualnej, połączonej z myślą postprocesualną

\footnotetext{
${ }^{26}$ Minta-Tworzowska 2000a, 2000b.

${ }^{27}$ Marciniak 2009, 2012c.

${ }^{28}$ Rączkowski 1996.

${ }^{29}$ Marciniak 1998, 2012a, 2012b.

${ }^{30}$ Minta-Tworzowska 2000e.
} 
(łączenie rygoryzmu i metodyzmu procesualnego $\mathrm{z}$ akceptacją wielogłosowości dyskursu archeologicznego oraz otwartością na wielość wizji pradziejów), akcentowanej na gruncie postprocesualizmu; (3) archeologii postprocesualnej/interpretatywnej: teoria społeczna $\mathrm{w}$ archeologii, archeologia kontekstualna, analiza i interpretacja reliktów kultury materialnej; (4) archeologii symbolicznej, wykorzystującej założenia strukturalizmu oraz poststrukturalizmu.

Teoria społeczna $w$ archeologii. Teoria społeczna $w$ archeologii może być ujmowana jako element wiążący wszystkie wymienione wyżej zainteresowania. Prace $\mathrm{z}$ tego nurtu poruszają interesującą problematykę, niemalże nieobecną w polskiej archeologii, zyskując $\mathrm{w}$ ten sposób ogromny potencjał interpretacyjny na rodzimym gruncie. Chodzi tutaj o ukazanie archeologii jako nauki rozwijającej problematykę społeczną, wchodzącą w zakres teorii społecznej ${ }^{31}$. Problematyka podejmowana na tym polu badawczym obejmuje szerokie spektrum zagadnień i jest rozumiana wieloaspektowo. Wśród nich do najbardziej znaczących zalicza się m.in. studia nad kategorią płci kulturowej (ang. gender archaeology), zagadnienie wieku jako istotnego czynnika kategoryzującego w pradziejach i badania nad kategorią dziecka i dzieciństwa w dyskursie archeologicznym ${ }^{32}$. Silnie eksponowane są również, w duchu archeologii postprocesualnej, badania nad procesami konstruowania w przeszłości tożsamości jednostki ludzkiej czy ciało ludzkie jako temat badawczy archeologii.

Symbole $i$ symbolika $w$ badaniach archeologicznych. Ważnym elementem rozwijanym w Zakładzie jest także problematyka symboli i symboliki w perspektywie badań archeologicznych, zwłaszcza w odniesieniu do sztuki pradziejowej ${ }^{33}$. Kwestia symboli i symboliki podnoszona jest często przez archeologów, jednak często na zasadzie intuicyjnej (,przedteoretycznej”), tutaj zaś doczekała się koherentnego, systematycznego ujęcia sposobów jej rozumienia i interpretowania. Charakteryzuje ją odrzucenie pozytywistycznych tez o możliwości wyczytania z nich realnie istniejącej (przeszłej) rzeczywistości, a pokazanie, jak z zastosowaniem określonych elementów teorii archeologicznej, np. założeń tekstualizmu, strukturalizmu czy poststrukturalizmu, zmienia się odczytanie i interpretacja sztuki pradziejowej. Ważnym aspektem w tym nurcie badawczym jest również zagadnienie rytuału w badaniach archeologicznych, a także możliwości interpretacji w tej perspektywie materialnych i symbolicznych aspektów śmierci oraz obrzędów pogrzebowych społeczności pradziejowych.

Archeologia lotnicza i metody nieinwazyjne. Istotnym zagadnieniem rozwijanym w Zakładzie od wielu lat jest archeologia lotnicza i refleksja nad statusem zdjęć lotniczych oraz ich wykorzystania w praktyce i interpretacji archeologicznej ${ }^{34}$. Zdję-

\footnotetext{
${ }^{31}$ Zob. Ciesielska 2002.

${ }^{32}$ Pawleta 2004, 2006, 2009.

${ }^{33}$ Minta-Tworzowska 2000d.

${ }^{34}$ Rączkowski 2002, 2004, 2005, 2009; Nowakowski, Prinke, Rączkowski 2005.
} 
cia lotnicze mają obecnie do spełnienia szczególną funkcję w poznaniu i ochronie dziedzictwa archeologicznego. Ich potencjał informacyjny powinien być szeroko wykorzystywany w badaniach i ochronie krajobrazu archeologicznego oraz jako pomoc w planowanych badaniach i podejmowaniu decyzji konserwatorskich, a także w upowszechnieniu wiedzy o dziedzictwie archeologicznym. Do spektakularnych sukcesów w tym zakresie można zaliczyć m.in. zidentyfikowanie zabudowy średniowiecznych Szamotul ${ }^{35}$ czy pozostałości kilkuhektarowego neolitycznego skupiska długich domów w pobliżu Jeziora Weneckiego na Pałukach ${ }^{36}$.

W ramach wspomnianego zagadnienia mieści się też ważny nurt, dotyczący „archeologii krajobrazu” (ang. landscape archaeology), i rozwijana refleksja teoretyczna, dotycząca zagadnień kulturowego konstruowania i percepcji krajobrazu/ przestrzeni. W studiach nad koncepcjami przestrzeni i krajobrazem pojęcia te rozumiane są nie tylko w kategoriach materialnych, biogeograficznych, lecz także ontologicznych czy estetycznych, mieszczących się właśnie w nurcie archeologii krajobrazu.

Jednym $\mathrm{z}$ istotnych problemów badawczych jest stosowanie wybranych metod komputerowych $\mathrm{w}$ archeologicznych badaniach nad przestrzenią, zwłaszcza tzw. GIS. Dane, uzyskane za pomocą geograficznych systemów informatycznych, stanowią jeden $\mathrm{z}$ bardziej istotnych składników analizy i interpretowania przestrzeni w przeszłości. Wskazać tu należy również wykorzystanie w archeologii metod geofizycznych. Zainteresowanie tą dziedziną badań archeologicznych powstało wraz z silnym rozwojem nowych technik prospekcji archeologicznej i możliwości, jakie niesie ów progres. Poruszane kwestie poszerzania tradycyjnego zakresu pytań badawczych o nowe sposoby nieinwazyjnego rozpoznawania materiałów archeologicznych doskonale wpisują się we współczesny wizerunek archeologii.

Archeozoologia. Ważnym zagadnieniem, rozwijanym przez Arkadiusza Marciniaka, jest też rozbudowana refleksja nad możliwościami poznawczymi badań szczątków faunistycznych z kontekstów archeologicznych ${ }^{37}$. Często w archeologii polskiej relacje między ludźmi a zwierzętami w przeszłości były odnoszone prawie wyłącznie do rekonstrukcji struktury stada czy struktury pogłowia, czyli dominacji aspektów gospodarczych. Rozwijane w Zakładzie zupełnie nowe, kompleksowe podejście oferuje wielowymiarowe spojrzenie na aspekty kulturowo-społeczne w odniesieniu do relacji między ludźmi a zwierzętami, tożsamości społecznej budowanej przez kontakty ze zwierzętami czy też sfery symbolicznej i religijnej, związanej ze zwierzętami. W zakres podejmowanej na tym polu problematyki wchodzą zagadnienia związane z metodyką analiz zooarcheologicznych oraz integracją wyników badań zwierzęcych szczątków kostnych z innymi rodzajami ewidencji źródło-

\footnotetext{
${ }^{35}$ Pietrzak, Rączkowski 2010.

${ }^{36}$ Harding, Rączkowski 2010.

${ }^{37}$ Zob. Marciniak 1996, 1999, 2005.
} 
wej, przy wyraźnie zdefiniowanej płaszczyźnie teoretycznej. W nurcie tym mieszczą się również badania tafonomiczne. Refleksja nad zooarcheologią obejmuje również problematykę procesów formowania, zwłaszcza mechanizmów tworzenia się depozytów kostnych, które stanowią podstawę wnioskowania dla archeologów oraz zooarcheologów.

Archeologia w spoteczeństwie. Ochrona i zarzqdzanie dziedzictwem archeologicznym. Przedmiotem zainteresowania pracowników są także problemy szeroko pojętego konserwatorstwa, muzealnictwa oraz ochrony, zarządzania i interpretacji dziedzictwa archeologicznego. Zagadnienia te odnoszą się do społecznej roli archeologii oraz potrzeby zdefiniowania na nowo jej roli we współczesnym świecie wobec zmieniających się uwarunkowań kulturowo-społecznych oraz ekonomicznych. Szczególną uwagę poświęcono tutaj społecznemu odbiorowi wiedzy o przeszłości, roli nowych mediów w popularyzowaniu rezultatów badań archeologicznych i archeologii. Zagadnienia realizowane na tym polu badawczym dotyczą m.in.: (a) roli i znaczenia przeszłości pradziejowej we współczesnym świecie oraz dla współczesnego człowieka; (b) społecznych kontekstów funkcjonowania archeologii i wytworów wiedzy archeologicznej, społecznych zobowiązań archeologii oraz jej wpływu na współczesną kulturę; (c) przedstawień przeszłości w postaci m.in. rezerwatów i skansenów archeologicznych, festynów archeologicznych, zjawiska odtwórstwa historycznego, komercjalizacji dziedzictwa przeszłości i archeologii, a także sposobów popularyzacji wiedzy o przeszłości za pomocą szeroko pojmowanych mediów ${ }^{38}$.

Ważny element namysłu i dydaktyki stanowi problematyka ochrony i zarządzania dziedzictwem archeologicznym oraz prawne aspekty jego zabezpieczania, a także próba odpowiedzi na pytanie, czym właściwie jest owa ochrona, oraz czy badania wykopaliskowe nie zagrażają zachowaniu dziedzictwa kulturowego dla przyszłych pokoleń. Doskonałym przykładem może być nowatorski ogólnoeuropejski kurs nauczania na odległość: „Dziedzictwo archeologiczne we współczesnej Europie" (2009), który spotkał się z bardzo pozytywnym odzewem i spełnił pokładane w nim oczekiwania ${ }^{39}$. Jego celem było przetestowanie aplikacji e-learningowych na potrzeby ochrony dziedzictwa archeologicznego i edukacji w tym zakresie. Szkolenie było skierowane do osób zawodowo zajmujących się archeologią. Wzięło w nim udział kilkudziesięciu pracowników służb konserwatorskich z całej Polski, pracowników nauki oraz studentów archeologii. Kurs trwał jednocześnie w kilku krajach partnerskich, brały w nim udział instytucje partnerskie z Niemiec, Holandii, Szwecji, Wielkiej Brytanii oraz Łotwy.

Wypada również wspomnieć o uczestnictwie pracowników Zakładu w międzynarodowym projekcie „Archaeology in Contemporary Europe: Professional Practi-

\footnotetext{
${ }^{38}$ Zob. Minta-Tworzowska, Olędzki 2006; Minta-Tworzowska 2006b, 2009; Marciniak, Minta-Tworzowska, Pawleta 2011; Pawleta 2011a, 2011b, 2012a, 2012b.

${ }^{39}$ Zob. Van Londen, Kok, Marciniak 2011.
} 
ces and Public Outreach", realizowanym w latach 2007-2012 we współpracy ośmiu partnerów z Grecji, Hiszpanii, Niemiec, Wielkiej Brytanii, Francji, Belgii, Holandii, Włoch i Polski, z udziałem zespołów badawczych z Węgier i Litwy. Był on koordynowany przez Institut National de Recherches Archéologiques Préventives z Paryża. Jego celem było systematyczne rozpoznanie wielu wyzwań, przed którymi staje współczesna archeologia europejska. Działania w projekcie prowadzone były w czterech wzajemnie uzupełniających się blokach: (a) znaczenie przeszłości dla teraźniejszości; (b) praktyki porównawcze w archeologii europejskiej; (c) archeologia jako profesja; (d) nowoczesne narzędzia zarządzania $\mathrm{w}$ archeologii. $\mathrm{W}$ procesie określenia współczesnej praktyki archeologicznej ${ }^{40}$ i próbach konceptualizacji przeszłości społecznej w ujęciu przedstawicieli wielu dyscyplin naukowych istotne były też prace redakcyjne Arkadiusza Marciniaka (wespół z S. Tabaczyńskim, A. Zalewską i D. Cyngot) nad przygotowaniem, w ramach „Komisji Antropologii Pradziejów i Średniowiecza”, tomu Przeszłość społeczna. Próba konceptualizacji ${ }^{41}$ oraz wkład pracowników Zakładu w przygotowanie poszczególnych haseł tego tomu.

\section{PODSUMOWANIE}

Żywimy nadzieję, że w tym krótkim przeglądzie udało się wykazać, iż refleksja nad rolą teorii $w$ archeologii, podejmowana $w$ ramach Zakładu, nie jest efektem uprawiania „teorii dla teorii”, ale wynika z przekonania, że zagadnienie teorii archeologicznej stanowi istotny i podstawowy element badań archeologicznych, na każdym etapie ich procedur badawczych, poznawczych oraz interpretacyjnych. $\mathrm{W}$ takie przeświadczenie wpisany jest pewien pragmatyzm, gdyż teoria spełnia podstawową, sterującą funkcję w badaniach archeologicznych, odnosząc się zarówno do praktyki badań archeologicznych, jak i sposobów interpretowania przeszłości. Podzielamy zatem przekonanie Matthew Johnsona ${ }^{42}$, że wszyscy archeolodzy, bez względu na uświadamianie sobie czy akceptowanie takiego stanowiska, w swej praktyce wykorzystują teorię na każdym etapie swych badań i konceptualizacji pradziejów. Istotna w tej perspektywie jest, podkreślana i realizowana w praktyce, konieczność odnoszenia teorii do źródeł archeologicznych, stanowiących podstawę badań archeologicznych. W naszym przekonaniu tylko taka teoria ma rację bytu i tylko taka świadczy o istotnej roli oraz aktywnym udziale archeologii we współczesnym dyskursie humanistycznym. To bowiem, co stanowi o sile i atutach tejże dyscypliny, to z jednej strony materialność przeszłości, z drugiej zaś: możliwości obserwowania zmian czy procesów w perspektywie długiego trwania. W taki sposób

\footnotetext{
${ }^{40}$ Zob. Marciniak 2006a.

${ }^{41}$ Tabaczyński, Marciniak, Cyngot, Zalewska 2012.

${ }^{42}$ Johnson 2010, xiv.
} 
archeologia, wykorzystując dwa przywołane wyżej elementy, może zabierać głos na zasadzie aktywnego współudziału w kluczowych debatach toczonych na gruncie współczesnej humanistyki, z jednoczesnym zachowaniem swej własnej, dyscyplinowej tożsamości i odrębności.

\section{BIBLIOGRAFIA}

Ciesielska A.

2002 Elementy teorii spotecznej $w$ archeologii: koncepcje grup, instytucji i struktur spotecznych, Poznań-Kalisz.

Harding A., Rączkowski W.

2010 Living on the lake in the Iron Age: new results from aerial photographs, geophysical survey and dendrochronology on sites of Biskupin type, Antiquity 84, s. 386-404.

Hensel W.

1971 Archeologia i prahistoria, studia i szkice, Wrocław.

1972 Zakres i zadania archeologii, Slavia Antiqua 20, s. 131-135.

Jankuhn H.

1983 Wprowadzenie do archeologii osadnictwa, Warszawa.

Johnson M.

2010 Archaeological theory. An introduction (2nd edition), Malden, Oxford.

Kuhn T.

1968 Struktura rewolucji naukowych, Warszawa.

Marciniak A.

1996 Archeologia i jej źródła. Materiały faunistyczne $w$ procesie badawczym archeologii, Poznań-Warszawa.

1998 Setting a new agenda. Ian Hodder and his contribution to archaeological theory, Archaeologia Polona 35-36, s. 409-426.

1999 Faunal materials and an interpretive archaeology. Epistemology reconsidered, Journal of Archaeological Method and Theory 6(4), s. 293-320.

2005 Placing animals in the Neolithic. Social zooarchaeology of prehistoric farming communities, London.

2006a Central European archaeology at the crossroads [w:] A future for archaeology. The past in the present, red. R. Layton, S. Shennan, London, s. 157-171.

2006b Theorizing archaeological practice. An outline, Archaeologia Polona 44, s. 41-52.

2009 Poznawanie i przedstawianie przeszłości - dylematy współczesnej archeologii pradziejowej [w:] Narracja, historia, fikcja. Dawne kultury w historiografii i literaturze, red. Ł. Grützmacher, Warszawa, s. 229-237.

2012a Paradygmaty badawcze w archeologii [w:] Przeszłość społeczna. Próba konceptualiza$c j i$, red. S. Tabaczyński, A. Marciniak, D. Cyngot, A. Zalewska, Poznań, s. 29-83.

2012b Teoria w archeologii [w:] Przeszłość spoteczna. Próba konceptualizacji, red. S. Tabaczyński, A. Marciniak, D. Cyngot, A. Zalewska, Poznań, s. 84-116.

2012c Przedstawianie i narratywizm w archeologii [w:] Przeszłość społeczna. Próba konceptualizacji, red. S. Tabaczyński, A. Marciniak, D. Cyngot, A. Zalewska, Poznań, s. 162 -177.

Marciniak A., Rączkowski W.

1991 The development of archaeological theory in Poland under conditions of isolation, Word Archaeological Bulletin 5, s. 57-65. 
Minta-Tworzowska D.

1987 Kwestia postępu poznawczego w prahistorii, Folia Praehistorica Posnaniensia 2, s. 5-12.

1994 Klasyfikacja jako sposób wyrażania wyników badań, hipotez i teorii archeologicznych, Poznań.

1998a Jerzego Topolskiego koncepcja źródła historycznego a ujęcia źródeł archeologicznych [w:] Świat historii: prace z metodologii historii $i$ historii historiografii dedykowane Jerzemu Topolskiemu z okazji siedemdziesięciolecia urodzin, red. W. Wrzosek, Poznań, s. 329-340.

1998b Continuity and change of classification in archaeology [w:] Theory and practice of archaeological research, t. III: Dialogue with the data: The archaeology of complex societies and its context in the '90, red. S. Tabaczyński, Warszawa, s. 191-223.

2000a Postmodernizm, myśl poststrukturalistyczna a archeologia (zarys problematyki) [w:] Archeologia w teorii i praktyce, red. A. Buko, P. Urbańczyk, Warszawa, s. 87-95.

2000b Archeologiczne rekonstrukcje świata pradziejowego wobec krytyki postmodernistycznej [w:] Kultury archeologiczne a rzeczywistość dziejowa, red. S. Tabaczyński, Warszawa, s. 185-195.

2000c Ś Świat archeologii w świetle źródeł archeologicznych, Acta historica et museologica Universitatis Silesianae Opaviensis 5, s. 49-59.

2000d Symbole i symbolika w perspektywie badań archeologicznych [w:] Kultura symboliczna kręgu pól popielnicowych epoki brąu i wczesnej epoki żelaza w Europie Środkowej, red. B. Gediga, D. Piotrowska, Warszawa-Wrocław-Biskupin, s. 45-54.

2000e Kwestia przełomu metodologicznego w archeologii i prahistorii polskiej [w:] Archeologia i prahistoria polska w ostatnim pótwieczu, red. S. Kurnatowski, M. Kobusiewicz, Poznań, s. 527-537.

2002 Between a community of inspiration and the separateness of archaeological traditions [w:] Archaeologies of Europe. History, methods and theories, red. P. Biehl, A. Gramsch, A. Marciniak, Münster, s. 54-64.

2006a Interdisciplinary research and archaeology, Archeologia Polona 44, s. 41-51.

2006 b Archeolog i inni ,kulturolodzy” wobec pytania o potrzebę przeszłości [w:] Коти роtrzebna jest przeszłość?, red. D. Minta-Tworzowska, Ł. Olędzki, Poznań, s. 26-33.

2009 Do kogo ,należy” przeszłość Biskupina?, Przeglad Archeologiczny 57, s. 7-22.

2012 Źródło - ślad - artefakt - rzecz - przedmiot [w:] Przeszłość społeczna. Próba konceptualizacji, red. S. Tabaczyński, A. Marciniak, D. Cyngot, A. Zalewska, Poznań, s. 137-161.

Minta-Tworzowska D., Marciniak A., Pawleta M. (red.)

2011 Współczesne oblicza przeszłości, Poznań.

Minta-Tworzowska D., Olędzki Ł.

$2006 \quad$ Komu potrzeba jest przesztość?, Poznań.

Minta-Tworzowska D., Rączkowski W.

1996 Theoretical traditions in contemporary Polish archaeology, World Archaeological Bulletin 8, s. 196-209.

2007 Standardy teoretyczne we współczesnej polskiej archeologii [w:] Pót wieku z dziejów archeologii polskiej 1939-1989, red. J. Lech, Warszawa, s. 219-247.

Nowakowski J., Prinke A., Rączkowski W. (red.)

2005 Biskupin... i co dalej? Zdjęcia lotnicze w polskiej archeologii, Poznań.

Pałubicka A., Tabaczyński S.

1986 Społeczeństwo i kultura jako przedmiot badań archeologicznych [w:] Teoria i praktyka badań archeologicznych. Przestanki metodologiczne, t.1, red. G. Donato, W. Hensel, S. Tabaczyński, Wrocław-Warszawa, s. 57-148. 
Pawleta M.

2004 Re-konstruowanie dzieciństwa w archeologii [w:] Dusza maluczka, a strata ogromna. Funeralia Lednickie. Spotkanie 6, red. W. Dzieduszycki, J. Wrzesiński, Poznań, s. 87-97.

2006 Where do we stand? Exploring the contours of gendered archaeology, Archaeologia Polona 44, s. 53-75.

2009 Archeologia dzieciństwa, Sprawozdania Archeologiczne 61, s. 9-38.

2011a Przeszłość jako źródło przyjemności, Przegląd Archeologiczny 59, s. 27-54.

2011b „Przemysł przeszłość”: wybrane aspekty komercjalizacji przeszłości i produktów wiedzy archeologicznej we współczesnej Polsce, Sprawozdania Archeologiczne 63, s. 9-54.

2012a Obrazy przeszłości w narracjach współczesności [w:] Przeszłość spoteczna. Próba konceptualizacji, red. S. Tabaczyński, A. Marciniak, D. Cyngot, A. Zalewska, Poznań, s. $1145-1162$.

2012b Rekonstrukcje i inscenizacje przeszłości w perspektywie turystyki archeologicznej w Polsce [w:] Skanseny archeologiczne i archeologia eksperymentalna, red. J. Gancarski, Krosno, s. 415-438.

Pietrzak R., Rączkowski W.

2009 Od przybytku głowa... boli. O kontekście i konsekwencjach odkrycia pierwszej lokacji Szamotuł [w:] Szamotuły. Karty z dziejów miasta, t. 2, red. I. Skierska, Szamotuły, s. 9-26.

Piontek J. (red.)

$1988 \quad$ Szkice z antropologii ogólnej: propozycje teoretyczno-metodyczne badań spoteczeństw pradziejowych, Poznań.

Rączkowski W.

1996 "Drang nach westen"? Polish archaeology and national identity [w:] Nationalism and archaeology in Europe, red. M. Díaz-Andreu, T. Champion, London, s. 187-217.

2002 Archeologia lotnicza - metoda wobec teorii, Poznań.

2004 Przeszłość uchwycona? Kilka refleksji nad fotografią i badaniem przeszłości [w:] Umyst i kultura, red. A. Pałubicka, A. Dobosz, Bydgoszcz, s. 147-158.

2005 Tradition in power: vicious circle(s) of aerial survey in Poland [w:] From the air: understanding aerial archaeology, red. K. Brophy, D. Cowley, Stroud, s. 151-167.

2009 Zobaczyć ukryte. Zdjęcia lotnicze w archeologii [w:] Studia nad dawna Polska, t. 2, red. T. Sawicki, Gniezno, s. 133-154.

2009/2011 Theory, empiricism and practice: archaeological discourses in a network of dependency and opposition, Analecta Archaeologica Ressoviensia 4, s. 7-34.

2012a The "German School of Archaeology" in its Central European context: sinful thoughts [w:] A history of Central European archaeology. Theory, methods, and politics, red. A. Gramsch, U. Sommer, Budapest, s. 197-214.

Szacki J.

2001 Historia i mitologia, Res Publica Nowa 7, s. 53-57.

Tabaczyński S.

1985 Zjawisko nieciągłości jako przedmiot analizy archeologicznej, Folia Praehistorica Posnaniensia 1, s. 7-22.

Tabaczyński S., Marciniak A., Cyngot D., Zalewska A. (red.)

2012 Przesztość spoteczna. Próba konceptualizacji, Poznań.

Van Londen H., Kok M.S.M., Marciniak A. (red.)

2009 E-learning archaeology: theory and practice, Amsterdam.

Żak J.

1966 Historia pierwotna i jej współczesne metody, Studia Metodologiczne 2, s. 67-89.

1968 Archeologia w systemie nauk historycznych, Archeologia Polski 13 (2), s. 455-473. 
1974 Słowianie i Germanie w prahistorii polskiej i niemieckiej [w:] Stosunki polsko-niemieckie w historiografii, t. 1, red. J. Krasucki, G. Labuda, A. Walczak, Poznań, s. 21-149.

1974/1975 Próba przedmiotowego modelu kultury społeczeństw młodszego i schyłkowego paleolitu (strefy śródziemnomorskiej), Fontes Archaeologici Posnanienses 25, s. 28-59.

1975 Uwagi teoretyczne o refleksji prahistorycznej, Archeologia Polski 20 (2), s. 259-273.

1977 O studiach osadniczych, Archeologia Polski 22, s. 421-424.

1980 Kwestia kontynuacji i dyskontynuacji w V/VI wieku (materiały do dyskusji) [w:] Materiat pomocniczy w ramach problemu R-III-6, Kraków, s. 1-8.

1985a Uwagi metodologiczne nad problemem osadnictwa, Studia Metodologiczne 24, s. 77-87.

1985b O kontynuacji i dyskontynuacji społecznej i kulturowej na ziemiach nadodrzańskich i nadwiślańskich w V-V/VI w. n.e., Folia Praehistorica Posnaniensia 1, s. 85-105.

1988 Wprowadzenie [w:] Szkice z antropologii ogólnej: propozycje teoretyczno-metodyczne badań społeczeństw pradziejowych, red. J. Piontek, Poznań, s. 9-12.

\section{THEORY AND METHODOLOGY OF ARCHAEOLOGY AT THE UNIVERSITY IN POZNAŃ}

\section{S u m mary}

The article attempts to present and evaluate the role and achievements of the Department of History and Methodology of Prehistory at the Institute of Prehistory at Adam Mickiewicz University, in terms of a reflection on theory and methodology of archaeology, developed in the framework of the Department, and pioneered by Professor Jan Żak. The first part of the article provides a general overview of the theoretical reflection and the range of issues undertaken by Professor Jan Żak. The overview of the theoretical and methodological problems reflects a wide range of issues, research questions, undertook by Professor, which were relevant within contemporary archaeology. He posed traditional questions, but as he went beyond traditional answers, it was not universally accepted.

One of the issues he regarded was a term to name the discipline, thus archaeology and its relation to prehistory. Jan Żak, like Witold Hensel, found discipline, synthesising prehistory, an equivalent of history in preliterate times; while the prehistoric archaeology as an independent discipline, basic for prehistory, and "auxiliary" for various types of history. Another area of his reflection was searching for theory. He criticised the positivist archaeology as pre-theoretical, with its inductionism and naturalism, and turned towards Marxism and structuralism as a social theory, through which archaeology would be able to make a breakthrough in methodology. Żak's idea was to transform archaeology into a discipline with a constant theory explaining prehistory. Professor also opted for a theoretical approach to science, the consequence of which was turning his interest towards social issues, with less attention paid to cultural problems, which was illustrated by his attempts to introduce a modelling approach towards transformations and processes taking place in the prehistory and the early Middle Ages, while applying the principle of contradiction to refer to basic economic factors. At the same time he argued with the second option, with Janusz Piontek's theory of biocultural evolution, however, he was aware of positive consequences of adapting this theory into archaeology. He believed that different theoretical approaches towards the same issues 
were the source of scientific progress. Żak's desire was to find a theory that would allow archaeology to go further than broadly understood positivism. It can be seen in all his works that he believed in existence and formulation of clear theoretical and methodological foundations. This has been particularly clear in the study of settlement. An important theoretical, methodological and practical issue was also a question of continuation of a settlement in the current Polish lands in fifth/sixth centuries AD. Żak attempted to reformulate the positivist problem of "continuity/discontinuity" of settlement, understood in terms of continuity of the presence of artefacts in continued sequence of cultural layers in the area. Professor introduced the theoretical understanding of the spatial, temporally and functionally diverse transition process, explaining it as a matter of continuity or discontinuity of a social and cultural self.

In the second part of the article an overview of the problems and issues, undertaken within the Department of History and Methodology of Prehistory has been presented, these concerned when Professor Jan Żak was still alive, but mostly after his death. It is too large to fit in a systematic approach, as the intellectual paths of the researchers from the Department reflect their own attempts to search for paradigms and their self-reflection on the role of theory in archaeology. An important issue, also illustrating a specific nature of the Department and problems undertaken and reflection developed within its framework seems the postulate of interdisciplinarity in research, not only in theory, but also in practice, through, inter alia, referring to the methodology of the humanities, philosophy of science, methodology of history, cultural anthropology, sciences (research procedures, empirical basis), or picking up an active voice in the deliberations within the contemporary humanities. Its purpose is to conceptualize study and practice of archaeology in the twentyfirst century. Among the research areas several leading ones might be distinguished, namely: (1) concept of a source in archaeology; (2) a classification and typology in archaeology; (3) a theory and methodology of archaeology: in its framework the broad mainstream of reflection, which may be related to several issues, namely the critique of positivist archaeology (cultural and historical), the search for a paradigm in a multitude of theories, the role of social theory in archaeology; (4) symbols and symbolism within archaeological research; (5) aerial photography and noninvasive methods; (6) archaeozoology; and (7) archaeology in society, as well as preservation and management of archaeological heritage. What all of these have in common when undertaken within the Department, is an attempt to find answers to questions about what is a "theory" in archaeology, what is its relationship with the practice of the discipline, the humanities and the intellectual world in general, as well as the role it played in the development of Polish archaeology in the past few decades.

The authors hope that this brief review has demonstrated that the reflection on the role of theory in archaeology, taken within the Department, is not the result of practicing the "theory for theory's sake", but stems from the belief that archaeological theory is important and basic in archaeological research at every stage of their research, cognitive and interpretational procedures.

Translated by Lucyna Leśniak 